\title{
BACTERIAL PROFILE OF RETAIL RABBIT CARCASSES MARKETED IN BENI-SUEF PROVINCE, EGYPT
}

\author{
FATMA H.M. ALI; ABDEL-RAHIM H.A. HASSAN and AHMED E.M. BAHGAT \\ Food Hygiene Department, Faculty of Veterinary Medicine, Beni-Suef University, Beni-Suef 62511, Egypt
}

Received: 8 March 2016; Accepted: 12 April 2016

\begin{abstract}
The current study aimed to evaluate the bacteriological status of retail rabbit carcasses marketed in Beni-Suef province, Egypt. For such aim, a total of 25 fresh rabbit carcasses were randomly collected from different rabbit markets in Beni-Suef during 2015. The collected samples were subjected to determination of aerobic plate count (APC) at $35{ }^{\circ} \mathrm{C}$, and most probable number (MPN) of coliforms, faecal coliforms and E. coli, in addition to isolation and identification of E. coli (true faecal type), Salmonella spp. and Yersinia enterocolitica. The obtained results revealed that 32,64, 72 and $52 \%$ of examined rabbit meat samples from shoulder, loin, rib and thigh regions, respectively, exceeded the acceptable limits recommended by Egyptian standards for APC (10 5 $\mathrm{CFU} / \mathrm{g}$ flesh). While none of the examined samples exceeded the international standards $\left(10^{7} \mathrm{CFU} / \mathrm{g}\right)$ stated by the International Commission on Microbiological Specification for Foods (ICMSF). Regarding the pathogenic microorganisms, it was found that $11(44 \%), 8(32 \%), 15(60 \%)$ and $10(40 \%)$ out of 25 rabbit cuts contained E. coli biotype I in shoulder, loin, rib and thigh regions, respectively. However, 3 (12\%), 3 (12\%), 3 (12\%) and 2 (8\%) samples contained Salmonella spp., and 3 (12\%), $3(12 \%), 6(24 \%)$ and 7 (28\%) contained Yersinia enterocolitica, respectively. The public health significance of isolated pathogens and their sources of contamination were discussed throughout the study.
\end{abstract}

Key words: Rabbit meat, Bacterial profile, E.coli, Salmonella, Yersinia entrocolitica.

\section{INTRODUCTION}

Rabbit meat is a highly desirable food, which represents a good source of animal protein of a high biological value. It contains all essential amino acids required for human nutrition as well as a higher proportion of unsaturated fatty acids and less cholesterol than other kinds of animal meats (Gergis, 2004). Rabbit meat has a highly palatable and digestible quality for consumers all over the world, and can be used as a subsidiary animal food due to their short generation interval, high fecundity and rabbit growth rate. Rabbit meat consumption is mainly developed in Mediterranean countries of the EU. It is considered by the traditional consumer to have positive sensory properties such as tenderness, low fat and delicately flavored, although a main cause of refusal is its typical wild taste (Dalle Zotte, 2002).

Bacteriological contamination is one of the main risk conditions that affects meat quality (including rabbit) and public health such as; Salmonella spp., Yersinia enterocolitica, Escherichia coli, which are

Corresponding author: Dr. ABDEL-RAHIM H.A. HASSAN E-mail address: abdelrahim@vet.bsu.edu.eg

Present address: Food Hygiene Department, Faculty of Veterinary Medicine, Beni-Suef University, Beni-Suef 62511, Egypt object of public health certification because of the potential risks they represent in diseases transmitted by food (Plym and Wierup, 2006). Each processing stage during rabbit meat preparation, from farm to fork, will add microbial contaminants to the initial bacteria count and thus decrease the keeping quality of the meat. Determination of the numbers and types of microorganisms contaminating the animal carcass is vital, from the standpoint of public health, for judging the effectiveness of sanitary measures during processing, and for estimating the quality characteristics including shelf-life (Buttler et al., 1979).

Salmonellae, E. coli and Yersinia enterocolitica are considered as three of the most common food-borne pathogens in developing countries as well as in developed ones, although their incidence varies from one country to another (Henson, 2003).

The microbiological quality of rabbit carcasses and changes during processing have not been studied in such depth as for other meats, accordingly, information on the microbiological quality of rabbit meats in Egypt is scarcely found (Abou-Taleb, 1995; Ali et al., 2015 and Khalafalla, 1993). Therefore, the current study was designed in order to evaluate the bacterial profile of rabbit carcasses marketed in Beni- 
Suef province through the determination of the aerobic plate count (APC) at $35{ }^{\circ} \mathrm{C}$, and most probable number (MPN) of coliforms, faecal coliforms and E. coli. In addition to the isolation and identification of E. coli biotype I, Salmonella and Yersinia enterocolitica.

\section{MATERIALS AND METHODS}

\section{Collection of the samples:}

A total of 25 fresh rabbit carcasses of native breeds were randomly collected from different rabbit markets at Beni-Suef province; the rabbits were slaughtered, dressed, eviscerated at the same day of collection at the markets by the markets' workers. Three rabbits were collected weekly and all of the collected rabbits were apparently sound at the time of collection. Then the rabbit carcasses were identified and wrapped in a sterile polyethylene bags and directly transferred in an icebox with a minimum of delay to the laboratory for further preparation and examination.

\section{Preparation of the samples:}

Preparation of the meat sample was carried out according to the muscle maceration technique recommended by AOAC (1990). Briefly; by using sterile instruments, $25 \mathrm{~g}$ of rabbit meat were aseptically removed from the deep tissues after surface sterilization using hot spatula of each rabbit primal cut; shoulder, rib, loin and thigh regions, according to Aduku and Olukosi (1990), then transferred into sterile homogenizer flask containing $225 \mathrm{ml}$ of $0.1 \%$ sterile buffered peptone water (Biolife; Italy). The contents were homogenized at 2000 r.p.m. for $2.5 \mathrm{~min}$ using sterile homogenizer (MPW 302, Universal Laboratory Aid, made in Poland). The homogenate was allowed to stand for about $15 \mathrm{~min}$ at room temperature. The contents of the flask represent the dilution $10^{-1}$ were thoroughly mixed by shaking, one $\mathrm{ml}$ was aseptically transferred using a sterile pipette into sterile test tube containing $9 \mathrm{ml}$ of $0.1 \%$ sterile buffered peptone water to be diluted in a sequential manner by tenfold serial dilution up to $10^{-6}$.

\section{Bacteriological examination:}

\subsection{Determination of $\mathrm{APC}$ at $35^{\circ} \mathrm{C}$ :}

The pouring plate technique recommended by AOAC (1990) was applied. Briefly, one $\mathrm{ml}$ from each dilution was separately pipetted into a double set of sterile Petri dishes. $15 \mathrm{ml}$ of melted standard plate count agar (Biolife; Italy) tempered at $45^{\circ} \mathrm{C}$ were poured into each Petri dish, then thoroughly mixed and left to solidify. The inoculated plates were incubated in an inverted position at $35^{\circ} \mathrm{C}$ for $48 \pm 2$ hours. The plates that contain colonies between 30 and 300 were counted, and then the average count was multiplied by the dilution factor to get $\mathrm{APC} / \mathrm{g}$ according to the following formula:

\section{APC /g = Average number of colonies $\mathrm{x}$ dilution} factor.

\subsection{MPN of Coliforms, Faecal coliforms and E. coli:}

The three tubes MPN method recommended by AOAC (1990) was used. In brief, regarding the MPN of coliforms, Lauryl Sulphate Tryptose broth (LST) with inverted Durham's tube was used for presumptive coliforms count followed by a confirmatory step through using sterile test tubes containing Brilliant Green Bile Lactose broth (BGBL) with inverted Durham's tube for positive LST tubes. For faecal coliforms MPN, sterile test tubes containing E. coli broth (EC) with inverted Durham's tube were incubated at $44 \pm 0.5^{\circ} \mathrm{C}$. While for E. coli MPN, a loopful from each positive EC broth tube was streaked onto the surface of Eosin Methylene Blue agar plate. The plates showing typical E. coli colonies (greenish metallic nucleated with dark purple center with or without sheen) were recorded. The MPN of each of coliforms, faecal coliforms and E. coli per $g$ of rabbit meat was estimated according to the three tubes MPN table using the following equation:

$\mathrm{MPN} / \mathrm{g}=$ Number from the table $\times$ middle dilution factor/100

3.4. Isolation and identification of $E$. coli biotype I: Suspected colonies of $E$. coli were subjected for further identification according to the method reported by AOAC (1990). Concisely, a stained smear with Gram`s stain was prepared from a separate colony to be examined microscopically. Then the suspected colonies were biochemically identified using indole production (I), methyl red (M), voges proskauer (Vi) and citrate utilization (C) tests. Where the samples gave E. coli specific IMViC pattern (+ - + -) were considered as E. coli biotype I.

\subsection{Yersinia enterocolitica:}

For determination of Yersinia enterocolitica, the technique recommended by APHA (1992) was done as follows:

\subsubsection{Isolation of Yersinia spp.:}

a) Selective enrichment:

One $\mathrm{ml}$ of the previously prepared original homogenate was inoculated into a test tube contained $9 \mathrm{ml}$ of Modified Rappaport Vassilidis broth (Biolife; Italy), which then thoroughly mixed and incubated at $25^{\circ} \mathrm{C}$ for 3 days.

\section{b) Selective differential plating:}

A loopful of cold enrichment broth was streaked onto Yersinia selective agar base (CIN, Biolife; Italy) to which Yersinia selective supplement (Biolife; Italy) was added. The inoculated plates were incubated at $32{ }^{\circ} \mathrm{C}$ for $18 \mathrm{hrs}$. Suspected colonies (dark red "bull's 
eye" colonies surrounded by transparent border) were picked up onto a Nutrient agar slope for further identification.

\subsubsection{Identification of the isolates:}

A separate colony on Nutrient agar plate from each isolate was used for preparation of Gram`s stained smear for Microscopical identification. Then the biochemical identification of the suspected colonies was applied according the following procedures: to differentiate the genus Yersinia from other genera; motility test at $37{ }^{\circ} \mathrm{C}$, gas production from glucose fermentation, citrate utilization at $37{ }^{\circ} \mathrm{C}$, voges proskauer at $25{ }^{\circ} \mathrm{C}$ and $\mathrm{H}_{2} \mathrm{~S}$ production tests were done. Where isolates showing negative results with all pervious experiments were considered as Yersinia spp. While, Yersinia enterocolitica samples were identified from other Yersinia spp. using motility test at $25{ }^{\circ} \mathrm{C}$, citrate utilization at $25{ }^{\circ} \mathrm{C}$, urease and rhamnose fermentation tests. The samples that gave positive results with the first three experiments and failed to produce acid with the last one were considered as Yersinia enterocolitica.

\subsection{Isolation of Salmonella spp.:}

Isolation of Salmonella spp. from rabbit meat samples was carried out as reported in the ISO 6579:2002 protocol with slight modifications. Briefly, the previously prepared original dilution $\left(10^{-1}\right)$ was incubated at $37^{\circ} \mathrm{C}$ for $20-24 \mathrm{~h}$ as a pre-enrichment step. After that, $0.1 \mathrm{ml}$ of the cultured original dilution was inoculated into a tube containing $10 \mathrm{ml}$ sterile Rappaport Vassilidis soy broth (Biolife; Italy) for selective enrichment and further incubated at 41.5 $\pm 0.5^{\circ} \mathrm{C}$ for $24 \mathrm{~h}$. A loopful from incubated broth was streaked onto two selective plating media, which were brilliant green agar (BGA) and Xylose Lysine Desoxycholate agar (XLD). All the inoculated plates were incubated at $36 \pm 1{ }^{\circ} \mathrm{C}$ for $24 \mathrm{~h}$. Moderately large, moist, smooth, and colorless colonies with pink background on BGA and slightly transparent red colonies with black center on XLD agar were suspected as Salmonella. The characteristic colonies of Salmonella were further streaked on nutrient agar plates and incubated at $36 \pm 1{ }^{\circ} \mathrm{C}$ for $24 \mathrm{~h}$ for purification, and then on nutrient agar slopes for further identification and biochemical characterization. The initial identification step was done using Gram`s stain smears and oxidase test, all isolates showing Gram`s stain positive and/or oxidase positive were discarded. Then other isolates were biochemically tested using indole, methyl red, voges proskauer, citrate utilization, triple sugar iron (TSI), and urease tests as per the protocol described by Ewing (1986). The colonies showing Salmonella specific IMViC pattern $(-+-+)$ were further inoculated on TSI slants and colonies produced alkaline slant (pink) and acidic butt (yellow) with or without $\mathrm{H}_{2} \mathrm{~S}$ production (blackening) were tested for urea hydrolysis on urea agar slants. All the urease negative isolates were considered as biochemically confirmed Salmonella isolates.

\section{Statistical analysis:}

Data were subjected to analysis of variances (one way-ANOVA) according to Knapp and Miller (1992) using (SPSS Statistics 17.0) software program.

\section{RESULTS}

The results presented in Table (1) showed the APC in different primal cuts of examined rabbit meat samples. It was found that it ranged from $5.1 \times 10^{3}$ to $8.8 \times 10^{6}, 3.9 \times 10^{3}$ to $9.3 \times 10^{6}, 2.6 \times 10^{3}$ to $9.3 \times 10^{6}$ and $5.1 \times 10^{3}$ to $4.0 \times 10^{6}$, with mean values accounted for $1.5 \times 10^{6}, 1.1 \times 10^{6}, 1.2 \times 10^{6}$ and $5.7 \times 10^{5} \mathrm{CFU} / \mathrm{g}$ flesh in shoulder, loin, rib and thigh regions, respectively. Slightly higher results were recorded by Abou-Taleb (1995) and Hohn (1960), while approximately similar values were obtained by Shiffman (1961) and Sunki et al. (1978), and lower values were reported by Comin et al. (2008) and Khalafalla (1993).

Table 1: Statistical analytical results of $\mathrm{APC}$ at $35{ }^{\circ} \mathrm{C}$ in different cuts of examined rabbit carcasses (CFU/g) $(n=25)$.

\begin{tabular}{ccccccc}
\hline \multirow{2}{*}{ Carcass cuts } & \multicolumn{2}{c}{ Positive Samples } & Minimum & Maximum & Mean & $\begin{array}{c}\text { Standard } \\
\text { error }\end{array}$ \\
\cline { 2 - 3 } & No. & $\%$ & & & & \\
\hline Shoulder & 25 & 100 & $5.1 \times 10^{3}$ & $8.8 \times 10^{6}$ & $1.5 \times 10^{6}$ & $5.1 \times 10^{5}$ \\
\hline Loin & 25 & 100 & $3.9 \times 10^{3}$ & $9.3 \times 10^{6}$ & $1.1 \times 10^{6}$ & $4.3 \times 10^{5}$ \\
\hline Rib & 25 & 100 & $2.6 \times 10^{3}$ & $9.3 \times 10^{6}$ & $1.2 \times 10^{6}$ & $4.4 \times 10^{5}$ \\
\hline Thigh & 25 & 100 & $5.1 \times 10^{3}$ & $4.0 \times 10^{6}$ & $5.7 \times 10^{5}$ & $2.0 \times 10^{5}$ \\
\hline
\end{tabular}

From the data illustrated in Table (2), it could be concluded that the MPN of coliforms in examined rabbit meat samples ranged from $<3$ to $1.5 \times 10^{4},<3$ to $9.3 \times 10^{3},<3$ to $1.5 \times 10^{4}$ and 7.4 to $9.3 \times 10^{3}$, with mean values of $2.0 \times 10^{3}, 1.2 \times 10^{3}, 1.7 \times 10^{3}$ and $1.7 \times 10^{3}$ microorganisms/g meat in shoulder, loin, rib and thigh regions, respectively. Higher results of Coliforms (MPN) were detected by Abou-Taleb (1995) and Kpodékon et al. (2008), and lower results were obtained by Margüenda et al. (2012). 
Table 2: Statistical analytical results of coliforms MPN in different cuts of examined rabbit carcasses (microorganisms/g) $(\mathrm{n}=25)$.

\begin{tabular}{|c|c|c|c|c|c|c|}
\hline \multirow{2}{*}{ Carcass cuts } & \multicolumn{2}{|c|}{ Positive Samples } & \multirow{2}{*}{ Minimum } & \multirow{2}{*}{ Maximum } & \multirow{2}{*}{ Mean } & \multirow{2}{*}{$\begin{array}{c}\text { Standard } \\
\text { error }\end{array}$} \\
\hline & No. & $\%$ & & & & \\
\hline Shoulder & 23 & 92 & $<3$ & $1.5 \times 10^{4}$ & $2.0 \times 10^{3}$ & $7.3 \times 10^{2}$ \\
\hline Loin & 24 & 96 & $<3$ & $9.3 \times 10^{3}$ & $1.2 \times 10^{3}$ & $4.2 \times 10^{2}$ \\
\hline Rib & 24 & 96 & $<3$ & $1.5 \times 10^{4}$ & $1.7 \times 10^{3}$ & $7.5 \times 10^{2}$ \\
\hline Thigh & 25 & 100 & 7.4 & $9.3 \times 10^{3}$ & $1.7 \times 10^{3}$ & $4.1 \times 10^{2}$ \\
\hline
\end{tabular}

The aforementioned results in Table (3) outlined the MPN of faecal coliforms in different primal cuts of examined rabbit meat samples. The faecal coliforms MPN values ranged from $<3$ to $2.3 \times 10^{3},<3$ to
$4.3 \times 10^{3},<3$ to $4.3 \times 10^{3}$ and $<3$ to $4.3 \times 10^{3}$, and the mean values accounted for $2.9 \times 10^{2}, 6.6 \times 10^{2}, 5.5 \times 10^{2}$ and $1 \times 10^{3}$ microorganisms/g meat in shoulder, loin, rib and thigh regions, respectively.

Table 3: Statistical analytical results of faecal coliforms MPN in different cuts of examined rabbit carcasses (microorganisms/g) $(\mathrm{n}=25)$.

\begin{tabular}{ccccccc}
\hline \multirow{2}{*}{ Carcass cuts } & \multicolumn{2}{c}{ Positive Samples } & Minimum & Maximum & Mean & $\begin{array}{c}\text { Standard } \\
\text { error }\end{array}$ \\
\cline { 2 - 3 } & No. & $\%$ & & & & \\
\hline Shoulder & 23 & 92 & $<*$ & $2.3 \times 10^{3}$ & $2.9 \times 10^{2}$ & $1.1 \times 10^{2}$ \\
\hline Loin & 23 & 92 & $<3^{*}$ & $4.3 \times 10^{3}$ & $6.6 \times 10^{2}$ & $2.6 \times 10^{2}$ \\
\hline Rib & 24 & 96 & $<3^{*}$ & $4.3 \times 10^{3}$ & $5.5 \times 10^{2}$ & $2.4 \times 10^{2}$ \\
\hline Thigh & 23 & 92 & $<3^{*}$ & $4.3 \times 10^{3}$ & $1 \times 10^{3}$ & $2.6 \times 10^{2}$ \\
\hline
\end{tabular}

$*<3=0$

Concerning the MPN of E. coli illustrated in Table (4), it was observed that it ranged from $<3$ to $7.4 \times 10^{2}$, $<3$ to $2.3 \times 10^{3},<3$ to $2.3 \times 10^{3}$ and $<3$ to $2.3 \times 10^{3}$ microorganisms/g meat in shoulder, loin, rib and thigh regions, respectively. While the mean values were $8.7 \times 10,2.5 \times 10^{2}, 2.4 \times 10^{2}$ and $4.2 \times 10^{2}$ microorganisms/g meat, respectively.

Table 4: Statistical analytical results of E. coli MPN in different cuts of examined rabbit carcasses (microorganisms/g) $(\mathrm{n}=25)$.

\begin{tabular}{ccccccc}
\hline \multirow{2}{*}{ Carcass cuts } & \multicolumn{2}{c}{ Positive Samples } & \multirow{2}{*}{ Minimum } & Maximum & Mean & Standard error \\
\cline { 2 - 4 } & No. & $\%$ & & & & \\
\hline Shoulder & 21 & 84 & $<3^{*}$ & $7.4 \times 10^{2}$ & $8.7 \times 10$ & $3.6 \times 10$ \\
\hline Loin & 20 & 80 & $<3^{*}$ & $2.3 \times 10^{3}$ & $2.5 \times 10^{2}$ & $1.1 \times 10^{2}$ \\
\hline Rib & 23 & 92 & $<3^{*}$ & $2.3 \times 10^{3}$ & $2.4 \times 10^{2}$ & $1.2 \times 10^{2}$ \\
\hline Thigh & 22 & 88 & $<3^{*}$ & $2.3 \times 10^{3}$ & $4.2 \times 10^{2}$ & $1.0 \times 10^{2}$ \\
\hline
\end{tabular}

$*<3=0$

As regard to the incidence of isolated pathogens from examined rabbit carcasses, the illustrated data in Table (5) and Figure (1) showed that $11(44 \%), 8$ (32 $\%), 15(60 \%)$ and $10(40 \%)$ out of 25 rabbit cuts contained $E$. coli biotype I in shoulder, loin, rib and thigh regions, respectively.

Besides, the same table and figure revealed that 3 (12\%), 3 (12\%), $3(12 \%)$ and $2(8 \%)$ out of 25 rabbit meat samples contained Salmonella spp. in shoulder, loin, rib and thigh regions, respectively.

Furthermore, it could be clarified from Table (5) and Figure (1) that $3(12 \%), 3(12 \%), 6(24 \%)$ and 7 $(28 \%)$ out of 25 rabbit cuts contained Yersinia enterocolitica in shoulder, loin, rib and thigh regions, respectively. 
Table 5: Incidence of isolated pathogens from examined rabbit carcasses $(n=25)$.

\begin{tabular}{lcccccccc}
\hline \multirow{2}{*}{ Pathogens } & \multicolumn{2}{c}{ Shoulder region } & \multicolumn{2}{c}{ Loin region } & \multicolumn{2}{c}{ Rib region } & \multicolumn{2}{c}{ Thigh region } \\
\cline { 2 - 9 } & No. & $\%$ & No. & $\%$ & No. & $\%$ & No. & $\%$ \\
\hline E. coli (biotype I) & 11 & 44 & 8 & 32 & 15 & 60 & 10 & 40 \\
\hline Salmonella spp. & 3 & 12 & 3 & 12 & 3 & 12 & 2 & 8 \\
\hline Yersinia enterocolitica & 3 & 12 & 3 & 12 & 6 & 24 & 7 & 28 \\
\hline
\end{tabular}

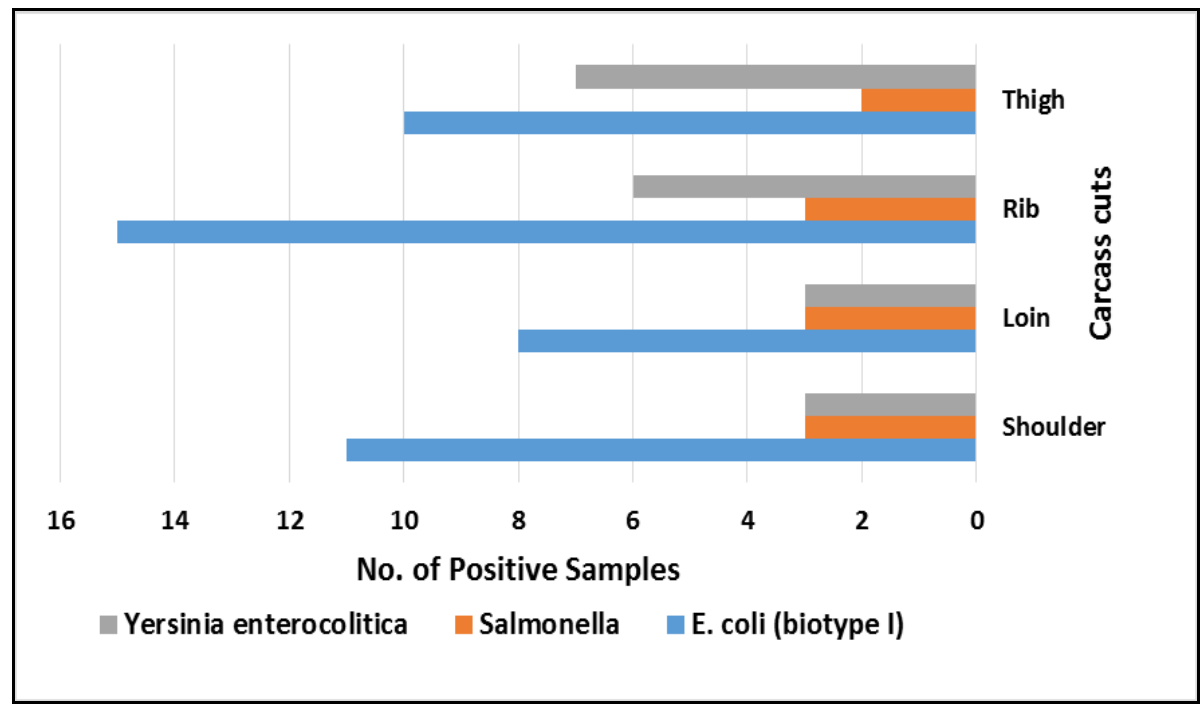

Figure 1: Incidence of isolated pathogens from examined rabbit primal cuts $(n=25)$

\section{DISCUSSION}

\section{Bacteriological counts of examined rabbit primal cuts:}

\section{1. $\mathrm{APC}$ at $35{ }^{\circ} \mathrm{C}$ :}

The high levels of aerobic plant counts found in the present study could be attributed to the bad hygienic measures observed during slaughtering, preparation and handling of carcasses at retail markets. These findings held the view reported by Finzi and Costa (1979) that equipment, air, water and workers are vehicles of microbial contamination of food. So that slaughtered rabbit carcasses generally have low bacterial count when slaughtered under high sanitary conditions, while during handling and processing the number of microorganisms increased significantly. Moreover, these reports are in accordance with the conclusion of Khalafalla (1993) that slaughtered rabbit carcasses from the groceries stores have higher bacterial counts than home slaughtered.

As regard to the permissible limits, it was obtained that $8,16,18$ and 13 out of 25 samples of examined rabbit meat samples from shoulder, loin, rib and thigh regions representing $32,64,72$ and $52 \%$, respectively, exceeded the maximum acceptable limits recommended by ES (2005) for aerobic plate count in chicken and rabbits $\left(10^{5} \mathrm{CFU} / \mathrm{g}\right.$ flesh). Comparatively with the acceptability limit of aerobic plate count $\left(10^{7} \mathrm{CFU} / \mathrm{g}\right.$ flesh $)$ stated by ICMSF (1986), it was found that none of the examined rabbit carcasses exceeded such level. In this respect, Özogul et al. (2004) stated when the aerobic plate count reaches $10^{6} \mathrm{CFU} / \mathrm{g}$ or $\mathrm{ml}$ in a food product, it is assumed to be at, or near, spoilage. On the other hand, Zambuchini et al. (2008) reported that standards, guidelines and specifications often use much lower bacterial population or total plate count as indices of acceptability.

From the present data, it could be concluded that unhygienic handling of rabbits during slaughtering, dressing, evisceration, storage and marketing is the main cause of higher total bacterial population.

\subsection{Coliforms MPN:}

Coliform group of bacteria in meat has been considered important in microbiological analysis on account of their significance as indicator organisms for pin painting the unhygienic conditions during handling and processing. Therefore, presence of coliforms in rabbit meat may be responsible for their inferior quality resulting in economic losses besides their presence in a great number may raise the public health risk (Mercuri and Cox, 1976; National 
Academy of Science, 1985). In conclusion, presence of coliforms in some of the examined rabbit carcasses in the current study could be attributed to the unhygienic and faulty methods of evisceration, preparation and handling, which were noticed during collection of the samples, these results run with that published by Libby (1975) and Miskimin et al. (1976).

\subsection{Faecal coliforms MPN:}

Lower values of faecal coliforms (MPN) in rabbit meat than those reported in the current study was determined by Abou-Taleb (1995). Presence of faecal coliforms in the examined rabbit carcasses in the present study is an indicative of faecal contamination and could be attributed to the faulty evisceration and/or the lack of proper personnel hygiene of workers. Such findings coincide with that obtained by Gonzalez-Rodriguez et al. (2001) and Youssef et al. (1985) that the presence of faecal coliforms in food is indicative of faecal contamination.

\subsection{E. coli MPN:}

Lower values of E. coli (MPN) than reported in the present study were demonstrated by Abou-Taleb (1995); Khalafalla (1993) and Velázquez et al. (2008). In this respect, Brown and Baird-Parker (1982) suggested that the analysis of foods of animal origin for the presence or levels of $E$. coli has been widely accepted as an indicator for fecal contamination. Moreover, the presence of such organism indicated the possibility of occurrence of microbiological hazards. Accordingly, these findings confirm the faecal contamination of examined rabbit carcasses during preparation.

\section{Incidence of studied pathogens in examined rabbit carcasses:}

\subsection{Escherichia coli (biotype I):}

The obtained incidences of E.coli biotype I indicate that positive samples are not acceptable according to the standards of E.coli in rabbit meat recommended by ES (2005) which stated that rabbit meat must be free from $E$. coli. Lower incidences of $E$. coli biotype I were obtained by Abou-Taleb (1995); Khalafalla (1993) and Velázquez et al. (2008). While RodríguezCalleja et al. (2006) could not isolate it from rabbit carcasses.

E. coli is an emerging cause of food borne illness and now is recognized as an important human pathogen, it is a ubiquitous commensal of the gastrointestinal tract where it presents in large numbers (Pennington, 1997). The isolation of biotype I E. coli from food samples is of a significant public health importance as consumption of such contaminated food may result in infantile diarrhea and gastroenteritis in adults (SapnaKumari et al., 2001). From the present study, it could be concluded that the isolation of biotype $E$. coli from the examined rabbit meat samples is an indicator of the existence of public health risks to consumers.

\subsection{Salmonella spp.:}

The detection of Salmonella spp. in some rabbit carcasses indicates that such samples are not acceptable according to the standard of Salmonellae in rabbit meat recommended by ES (2005) which has not set an acceptable limit for Salmonella spp. in rabbit carcasses. Almost similar results were reported by Khalafalla (1993). However, lower results were obtained by Comin et al. (2008) and Velázquez et al. (2008). While, Kpodékon et al. (2008) could not isolate Salmonellae from examined rabbit carcasses.

The source of contamination of slaughtered rabbit carcasses by Salmonella spp. could be due to bad personnel hygiene and/or unsanitary measures during carcass preparation; this held the view of Molla et al. (2003) who isolated Salmonellae from slaughtered animals with a percentage of $4.2 \%$ and from slaughterhouse personnel with a percentage of $6.0 \%$. Furthermore, these results are parallel to that reported by Samuel et al. (1980) that the leading source of contamination of carcasses by Salmonellae is the fault evisceration at the slaughterhouse. Regarding the public health significance of Salmonella spp., it was reported that Salmonella is the primary cause of food poisoning in Canada. It caused about $68 \%$ of microbial related food poisoning outbreaks (Lavigne, 1986). Furthermore, Plym and Wierup (2006) mentioned that non-typhoid salmonellosis in humans manifested as a localized enterocolitis, clinical signs usually begin 12 to $36 \mathrm{~h}$ after ingestion of a contaminated food, include diarrhea, nausea, abdominal pain, mild fever and chills.

\subsection{Yersinia enterocolitica:}

Yersinia enterocolitica is a psychrotrophic organism, which was associated with a variety of human illnesses, of which enterocolitis is the most frequent manifestation. The organism has become of a considerable public health significance, several outbreaks of foodborne infection caused by consumption of contaminated food by this organism (De-Boer et al., 1986).

Nearly similar results to those of our study were detected by Rodriguez-Calleja, et al. (2006), while Khalafalla (1993) could not isolate Yersinia enterocolitica from examined rabbit carcasses during his study.

The contaminated rabbit cuts in the present study with $Y$. enterocolitica could be attributed to the contamination of the water used for carcass washing and preparation. Moreover, it could happened by fault during evisceration. This substantiates the hypothesis that Yersinia enterocolitica could be isolated from a range of environmental sources including soil, fresh 
water and the intestinal tract of many animals (Adams and Moss, 1995). In this regard, it was recorded by Keet (1974) that the source of Yersinia enterocolitica may be from the cross-contamination between flesh and faeces.

\section{CONCLUSION}

From the present study, it could be concluded that unhygienic handling of rabbits during slaughtering, dressing, evisceration, storage and marketing is the main cause of high total bacterial population. The presence of considerable levels of faecal coliforms and $E$. coli in examined rabbit cuts is an indicator of faecal contamination of carcasses due to either fault evisceration or unclean area during preparation in the market. Higher incidences of biotype I E. coli in examined rabbit carcasses indicate the existence of public health risks to consumers. The presence of Salmonella spp. in examined rabbit cuts could be attributed to fault evisceration and/or lack of personnel hygiene, and this carries public health hazards to the consumers. While the isolation of $Y$. enterocolitica may be due to the contaminated water used during carcass washing and preparation.

\section{REFERENCES}

Abou-Taleb, S.M.S. (1995): Sanitary evaluation of slaughtered rabbits, MVSc Thesis, Faculty of Veterinary Medicine, Zagazig University, Egypt.

Adams, M.R. and Moss, M.O. (1995): Food Microbiology. Computape (Pickering) Ltd., North Yorkshire, Trowbridge, Wiltshire.

Aduku, A.O. and Olukosi, J.O. (1990): Rabbit management, Utilization, Economics, Practical training, Research and Future prospects, Living Book Services, G.U. Publication, Abuja; p: 111.

Ali, F.H.M.; Hassan, A-R.H.A. and Bahgat, A.E. (2015): Study of sumac extract (Rhus coriaria L.), lactic acid and thyme oil as decontaminants for shelf life extension of refrigerated rabbit meat. Food Sci Quality Manag, 38: 71-78.

AOAC (Association of Official Analytic Chemists) (1990): Official Methods of analysis. $15^{\text {th }}$ Ed., Association Official Analytic Chemist, Arlington VA, USA.

APHA (American Public Health Association) (1992): Compendium of methods for the microbial examination of food. 3rd Ed. American Public Health Association. Washington, DC. USA.

Brown, M.H. and Baird-Parker, A.C. (1982): The microbiological examination of meat. In: Brown, MH (Ed), Meat Microbiology. Applied Science Publishers, London, p. 423520.
Buttler, J.L.; Stewart, J.C.; Vanderzant, C.; Carpenter, Z.L. and Smith, G.C. (1979): Attachment of microorganisms to pork skin and surfaces of beef and lamb carcasses. J Food Protect, 42: 401-406.

Comin, D.; Mioni, R.; Gallocchio, L. and Maniero, C. (2008): Microbiological quality and safety of rabbit meat in Veneto Region-Italy. 9th WRCJune 10-13, Verona, Italy, pp. 1331-1335.

Dalle Zotte A. (2002): Perception of rabbit meat quality and major factors influencing the rabbit carcass and meat quality. Livestock Prod Sci, 75: 11-32.

De-Boer E.S.; Hartog, B.J. and Osterom, J. (1986): Occurrence of Yersinia enterocolitica in Poultry products. J. Food Prot, 45: 322-325.

ES (Egyptian Standards) (2005): Frozen poultry and rabbits. Egyptian Organization for Standardization and Quality Control, ES: 1090/2005

Ewing, W.H. (1986): Edwards and Ewing's Identification of Enterobacteriaceae. Fourth ed. Elsevier Science Publishing Co., Inc., New York.

Finzi, M. and Costa, C. (1979): Microbiological contamination in food processing plant preventive measures. Rivista della societa Italiane die scienza della's Alimentazione, 8: 258.

Gergis, A.H.K. (2004): Quality evaluation of frozen rabbit carcass. MSc Thesis, Fac. Vet. Med. Alexandria Univ., Egypt.

Gonzalez-Rodriguez, M.N.; Javier Sanz, J.; Santos, J.A.; Otero, A. and Garcia Lopez, M.L. (2001): Bacteriological quality of aquacultured freshwater fish portions in prepackaged trays stored at $3{ }^{\circ} \mathrm{C}$. J. Food Prot, 64: 1399-1404.

Henson, S. (2003): The Economics of Food Safety in Developing Countries. ESA Working Paper No. 03-19, December 2003. ftp://ftp.fao.org/ docrep/fao/007/ae052e/ae052e00.pdf. Last accessed on 24/3/2016.

Hohn, G. (1960): Unter suchungen uber der keimgehalt in Kuttelein, Mogleckeit der keim versuchlpung Fleschwirts chaft, 40: 19.

ICMSF (International Commission on Microbiological Specifications for Food) (1986): Microorganisms in Foods: Sampling for Microbiological Analysis, Principles and Scientific Applications, $2^{\text {nd }}$ ed., vol. 2. University of Toronto Press, Toronto, Buffalo, London.

ISO (International Organization for Standardization) (2002): Microbiology- General Guidance on Methods for the Detection of Salmonella. Fourth ed. ISO 6579/2002, Geneva, Switzerland.

Keet, E.E. (1974): Yersinia enterocolitica septicaemia. Source of infection and 
incubation period identified. New York State J. Med., 2226.

Khalafalla, F.A. (1993): Microbiological status of rabbit carcasses in Egypt. Zlebensm unters Forsch, 196: 1-3.

Knapp, R.G. and Miller, M.C. (1992): Clinical Epidemiology and Biostatics. Harwal Publishing, Pennsylvania.

Kpodékon, T.M.; Wabi, K.; Seydi, M.; Farougou, S.; Djago, A.Y. and Akpo, Y. (2008): Commercial and microbiological qualities of frozen rabbit carcasses in Benin. $9^{\text {th }}$ World Rabbit Congress, June 10-13/2008, Verona, Italy.

Lavigne, C. (1986): The Canadian salmonella and food-borne disease program. $2^{\text {nd }}$ World Congress Food- Borne Infection and Intoxication, Vol. (1), USA.

Libby, J.A. (1975): Meat Hygiene $4^{\text {th }}$ ED. LEA and Febiger, Philadelphia.

Margüenda, I.; Nicodemus, N.; Vadillo, S.; Sevilla, L.; García-Rebollar, P. and Villarroel, M. (2012): Effect of dietary type and level of fibre on rabbit carcass yield and its microbiological characteristics. Livestock Sci, 145: 7-12.

Mercuri, A.J. and Cox, N.A. (1976): Coliforms and Enterobacteriaceae isolated from selected Food. J. food Protect, 9: 712-714.

Miskimin, D.; Barkowitz, K.; Solberg, M.; Riha, W.E.; Frank, J.W.; Buchanan, R.L. and Leary, $V$. (1976): Relationship between indicator organisms and specific pathogens in potentially hazardous food. J. Food Sci, 41: 1001-1008.

Molla, B.; Alemayehu, D. and Salah, W. (2003): Sources and distribution of Salmonella serotypes isolated from food animals, slaughterhouse personnel and retail meat products in Ethiopia: 1997-2002. Ethip J Health Dev, 17: 63-70.

National Academy of Science (1985): An Evaluation of the Role of Microbiological Criteria for Foods and Food Ingredients. National Academy Press, Washington, D.C., USA.

Özogul, F.; Polat, A. and Özogul, Y. (2004): The effects of modified atmosphere packaging and vacuum packaging on chemical, sensory and microbiological changes of sardines (Sardina pilchardus). Food Chem, 85: 49-57.

Pennington, $H$. (1997): The Pennington group: report on the circumstance leading to the 1996 outbreaks of infection with E. coli $O_{157}$ in central Scotland, the implications for food safety and the lessons to be learned. The Stationary Office, Edinburgh. (Abst.).

Plym, L.F. and Wierup, M. (2006): Salmonella contamination: a significant challenge to the global marketing of animal food products. Rev Sci Tech, 25: 541-554.

Rodríguez-Calleja, J.M.; García-López, M.L.; Santos, J.A. and Otero, A. (2006): Rabbit meat as a source of bacterial foodborne pathogens. J. Food Protect, 69: 1106-1112.

Samuel, J.; OBoyle, D.; Mehters, W. and Frost A. (1980): Distribution of salmonella in the carcasses of normal cattle at slaughter. Res Vet. Sci., 28: 238-241.

Sapna-Kumari, K.; Prasad, B.N.; Gita Kumari, K.; Quasim, A. and Sinha, B.K. (2001): Prevalence of $E$. coli serotypes in market fish of Patna and its public health importance. Indian Vet J; 78: 851-852.

Shiffman, M.A. (1961): Microbiological standards of meat. Joint FAO/WHO Expert Committee on Meat Hyg. Rome II- 25 September, agenda item 202 (P.I.II).

Sunki, G.R.; Annapureddy, R. and Roo, D.R. (1978): Microbial biochemical and organoleptic changes in ground rabbit meat stored at 5 to 7 ${ }^{\circ} \mathrm{C}$. J Animal Sci; 46: 584-588.

Velázquez, O.V.; Alonso, F.M.U.; Lagunas, B.S.; Díaz, Z.S.; Gutiérrez, C.A. and Monroy, S.H. (2008): Microbial contamination levels in rabbit carcasses obtained from popular markets in Toluca valley, Mexico. $9^{\text {th }}$ World Rabbit Congress, 1455-1460.

Youssef, H.; El-Timawy, K. and Hefnawy, Y. (1985): Microbial quality of fresh water fish. J. Assiut Vet. Med.; 14: 109

Zambuchini, B.; Fiorini, D.; Verdenelli, M.C.; Orpianesi, C. and Ballini, R. (2008): Inhibition of microbiological activity during sole (Solea solea L.) chilled storage by applying ellagic and ascorbic acids. J. Food Sci Technol; 41: 1733-1738. 


\section{الصورة البكتيريـة لأبائح الأرانب المجز أة المسوقة في محافظة بني سويف - مصر \\ فاطمة حسن محمد علي ، عبل الرحيم حسين عبل العظيم حسن ، أحد الدرويش محمد بهجات \\ E-mail: abdelrahim@vet.bsu.edu.eg Assiut University web-site: www.aun.edu.eg}

تهدف الدر اسة الحالية إلى تقييم الوضع البكتريولوجي لذبائح الأر انب المجز أة المسوقة في محافظة بني سويف بمصر . لتحقيق هذا



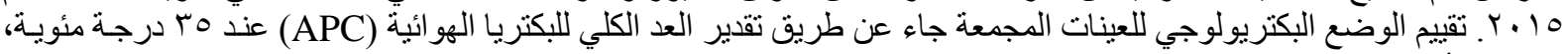

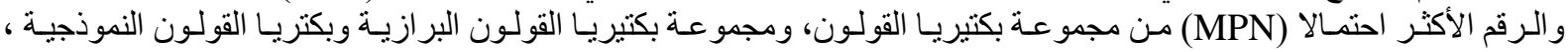

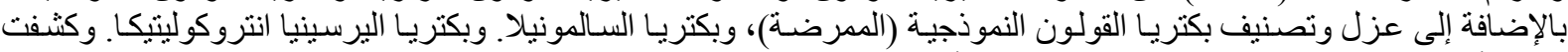

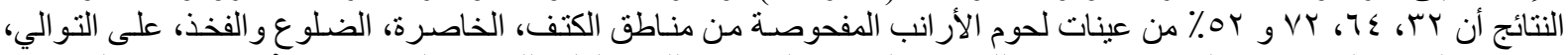

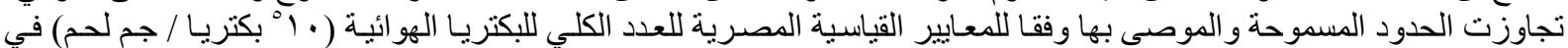

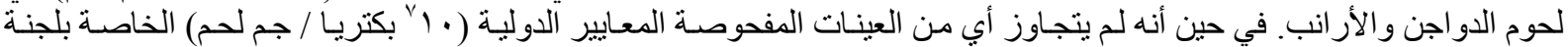
(ICMSF)

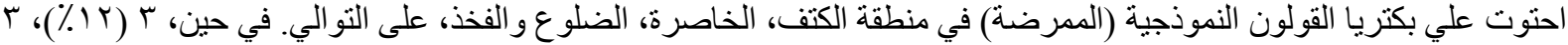

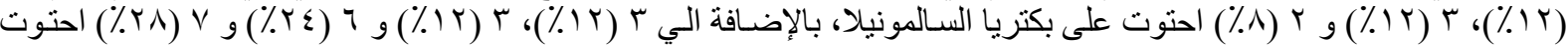

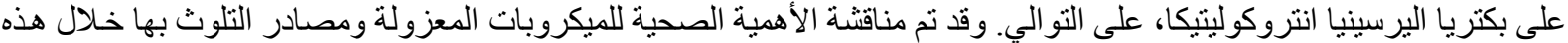

